DOI https://doi.org/10.30525/978-9934-588-80-8-1.28

\title{
ОСМИСЛЕННЯ РЕАЛІЙ ВІТЧИЗНЯНОЇ ІНКЛЮЗІЇ НА ОСНОВІ АНАЛІЗУ ТЕОРЕТИКО-МЕТОДОЛОГІЧНИХ ОСНОВ СВІТОВОЇ ОСВІТНЬОЇ ІНТЕГРАЦІЇ
}

\author{
Мухіна А. Ю. \\ кандидат психологічних наук, \\ дочент кафедри спеціальної та інклюзивної освіти \\ Д3 «Луганський національний університет імені Тараса Шевченка» \\ Серомаха H. $\mathbf{C}$. \\ кандидат психологічних наук, \\ дочент кафедри спеціальної та інклюзивної освіти \\ Д3 «Луганський національний університет імені Тараса Шевченка» \\ м. Старобільськ, Луганська область, Україна
}

Метою роботи $\epsilon$ аналіз сучасних реалій інклюзивної освіти в Україні; виявлення факторів, що перешкоджають впровадженню і розвитку інклюзивної освіти; визначення результативних напрямків вирішення існуючих проблем інклюзії.

За даними Міністерства соціальної політики, кількість людей 3 інвалідністю в відносних показниках збільшилася вдвічі порівняно 3 1990 роком. Якщо в 1990 їх налічувалося 3\% населення, то сьогодні кількість людей з особливими потребами в Україні сягає 6\% (близько 3 млн.), з яких понад 165 тисяч - діти. Зауважимо, що за часи війни в Україні кількість людей з інвалідністю збільшилася на кілька тисяч. Головна проблема для цієї категорії населення - вільний доступ до всіх можливостей сучасної цивілізації. Починаючи з вільного пересування по місту, і закінчуючи освітою і працевлаштуванням. Саме питання освіти в сучасному світі є принциповим [3].

У 2010 році Україна приєдналась до Конвенції про права інвалідів, прийнятої ООН в 2006 році, в якій проголошено обов'язок державучасниць Конвенції забезпечувати інклюзивна освіта на всіх рівнях $\mathrm{i}$ навчання протягом усього життя [3]. У 2018 році президент П. Порошенко підписав закон № 2249-VIII «Про внесення змін до деяких законодавчих актів України». Цим рішенням президент України вивів з ужитку слово «інвалід» [1].

Коли говорять про освіту дітей 3 особливими потребами, слід говорити про зміну базових принципів навчання. Вже тривалий час, 
західні країни просувають ідею всебічної інтеграції людей з інвалідністю в звичайний світ. Звідси виникає термін - інклюзія (в перекладі з англ. включення, інтеграція). Відповідно, інклюзивна освіта - надання рівного доступу до навчального процесу людям 3 особливими потребами. Інклюзивна освіта - це освітня система, головна мета якої долучити та забезпечити дітей, які мають інвалідність, потрібними знаннями в умовах загальноосвітнього закладу. Тобто, таке навчання передбачає створення освітнього середовища, яке б задовольняло потреби дітей з проблемами фізичного чи психологічного розвитку. Для європейських країн навчання дітей 3 особливостями розвитку та здорових однолітків разом має особливе значення, адже спілкування зі здоровими однокласниками та психологічна підтримка - головна ознака спеціальної освіти. Інклюзивна освіта поширена в Італії, Австрії, Португалії, Бельгії, Фінляндії, Люксембурзі, Іспанії, Німеччині, Ісландії, Ірландії, Великобританії, Швеції, Голландії, в кожній з цих країн, свій власний підхід та система інклюзивного навчання.

В Україні ситуація з інклюзивною освітою знаходиться на етапі зародження. Серед 17337 українських шкіл тільки 1127 залучені до інклюзивного навчання. Більше 56 тисяч школярів 3 особливими потребами мають можливості навчання в загальноосвітніх установах. Таким чином, показник інклюзії в Україні становить лише 7\%. Для порівняння: в Литві ця цифра сягає 90\%, Польщі - 42\%, Словаччини 42\%, Угорщині - 57\%, Італії - 99\%, Норвегії - 90\%, Франції - 25\% [5]. Включення дітей з особливими потребами в масові освітні установи передбачає спеціалізовану корекційну допомогу i психологічну підтримку, завданням яких $є$ контроль за розвитком дитини, успішність його навчання, надання допомоги у вирішенні проблем адаптації в середовищі здорових однолітків [1].

При аналізі процесу впровадження освітньої інтеграції в нашій країні, можна відзначити, що 3 двох організаційно-адміністративних моделей цього процесу, які існують у світовій практиці (модель «Поглинання» і модель «Співіснування»), Україна, як і США, обрала модель - «Поглинання», в якій порушений фундаментальний принцип освітньої інтеграції - свобода вибору місця навчання. Більшість європейських країн (а також Японія) реалізують іншу модель «Співіснування», не нехтуючи ключовими ідеями освітньої інтеграції [6]. Остання зі згаданих моделей дає дітям 3 особливостями психофізичного розвитку можливість вибору освітнього закладу, який якомога повніше сприяв би їхньому розвитку. На наш погляд, модель «Співіснування» можливо втілити в український освітній простір 
шляхом збереження загальної і спеціальної освіти за умови створення інклюзивних шкіл (інклюзивних класів).

Одним 3 найважливіших питань $є$ психологічний комфорт дітей $\mathrm{i}$ дорослих 3 психофізичними вадами, які потрапляють в активні соціальні стосунки 3 людьми, які не мають таких відхилень. Виникає питання: «Чи будуть вони почувати себе комфортно, знаходячись поруч зі здоровими однолітками»? Ряд досліджень доводять, що особи, які мають фізичні відхилення можуть досить впевнено і комфортно почувати себе поряд із здоровими однолітками, дещо складніше постає питання з дітьми, які мають інтелектуальні порушення [3].

Актуальним $\epsilon$ питання сприйняття іншими батьками дитини 3 порушеннями у розвитку в групі чи класі своєї здорової дитини. Ряд батьків звертають увагу на те, що дитині з порушеннями інтелекту чи інших функцій приділяється набагато більше уваги, ніж всім дітям класу. Чи правильно це?

Досить велике значення мають кадри (спеціалісти, які зможуть організувати навчальний процес i налагодити задовільний психологічний клімат, як з батьками та і в класі). Для того щоб побудувати ефективну систему інклюзивної освіти в Україні, передусім потрібно посилити фінансування освіти та удосконалити методичне та кадрове забезпечення інклюзивної освіти.

Недостатньо уваги приділяється доступності пришкільних територій: наявність під'їздів, паркувальних місць для осіб з інвалідністю, зокрема, для підвезення дітей на візках, обладнаних спортивних майданчиків для дітей з інвалідністю тощо. Дуже мало закладів освіти обладнано спеціальними туалетними кімнатами. Однак, слід наголосити, що ситуація поступово змінюється на краще. За оперативною інформацією наприкінці 2018-го безперешкодний доступ для осіб 3 особливими потребами до 1-го поверху забезпечений у 11560 закладах освіти, що становить 74\% від загальної кількості.

Якщо питання інклюзивної освіти в початковій і середній школі сьогодні знаходиться під особливою увагою, то у вищій школі ситуація складніша. За статистичними даними з 2,5 мільйонів студентів вітчизняних навчальних закладів I-IV рівнів акредитації, трохи більше 10 тисяч - люди 3 особливими освітніми потребами. На практиці це менше $1 \%$ від загальної кількості людей з інвалідністю працездатного віку (до 40 років). Питання надання освіти студентам 3 особливими освітніми потребами вирішуються лише у форматі адміністрації окремих вузів або місцевої влади. Наприклад, Національний педагогічний університет Драгоманова одним з перших в Україні почав розробляти цільові навчальні програми для студентів з інвалідністю 
(Науково-методичний центр освіти і соціальної реабілітації осіб 3 обмеженнями життєдіяльності).

Зміна структури спеціальної освіти та збільшення кількості дітей особливими освітніми потребами, «включених» до загальноосвітніх дошкільних та шкільних закладів, вимагає від педагогічних закладів вищої освіти (3ВО) перегляду і вдосконалення змісту і методів вищої освіти для підготовки педагогів до роботи в інклюзивних закладах. Постає необхідність врахування своєрідності реалізації освітньої парадигми, орієнтованої на пізнання індивідуальних потреб особливих учнів залежно від віку, характеру, ступеня порушення, якостей особистості; необхідність підтримки високого рівня викладання, що зумовлює пошуки «власного стилю» викладання, який повинен характеризуватися високим професіоналізмом та індивідуальним підходом до кожного студента; використання інтерактивних форм навчання, що дають змогу вже з самого початку навчання долучити студентів до практичної діяльності в рамках інклюзивної освіти; налагодження тісної взаємодії викладачів ЗВО 3 інклюзивними освітніми закладами для уточнення змісту навчальної і виробничої практик та проведення наукових досліджень.

\section{Література:}

1. Адаптована конвенція ООН щодо осіб з особливими потребами. Нью-Йорк, 13 грудня 2006 p. URL: www.osmhi.org/index.php?page=200 \&news=401\&pages (Дата звернення: 29.01.2019).

2. Данілавічютє Е. А. Стратегії викладання в інклюзивному навчальному закладі: навчально-методичний посібник. К. : Видавнича група «A.C.К.», 2012. 287 c.

3. Декларація про права інвалідів 2006 року URL: www.zakon.rada.gov.ua/cgi-bin/laws/main.cgi?nreg=995_117 (Дата звернення: 29.01.2019).

4. Гевко I. В. Значення інноваційних технологій при здійсненні інклюзивної освіти. Педагогічний альманах: збірник Комунального вищого навчального закладу Херсонська академія неперервної освіти Херсонської обласної ради. Херсон, 2018. Випуск № 37. С. 236-240.

5. Гриневич Л.M. 4 роки впровадження інклюзії URL: https://mon.gov.ua/ua/news (Дата звернення: 29.01.2019). 